\title{
Community-based evaluation of immigrant tuberculosis screening using interferon $\gamma$ release assays and tuberculin skin testing: observational study and economic analysis
}

\author{
Manish Pareek, ${ }^{1,2}$ Marion Bond, ${ }^{3}$ Jennifer Shorey, ${ }^{3}$ Suranjith Seneviratne, ${ }^{4}$ \\ Margaret Guy, ${ }^{5}$ Peter White, ${ }^{6,2}$ Ajit Lalvani, ${ }^{1}$ Onn Min Kon ${ }^{3}$
}

\begin{abstract}
- Additional materials are published online only. To view these files please visit the journal online (http://dx.doi. org/10.1136/thoraxjnl-2011201542).
\end{abstract}

For numbered affiliations see end of article

\section{Correspondence to} Dr Onn Min Kon, Consultant Respiratory Physician, Chest and Allergy Clinic, St Mary's Hospital, Imperial College Healthcare NHS Trust, Praed Street, London W2 1NY, UK onn.kon@imperial.nhs.uk

Independence The authors' work was independent of the funders, who had only a minimal role in the study design but no role in the analysis of data, writing of the manuscript or decision to submit for publication.

Received 3 January 2012 Accepted 16 May 2012 Published Online First 12 June 2012

\section{SLinked}

- http://dx.doi.org/10.1136/ thoraxjnl-2011-200956 - http://dx.doi.org/10.1136/ thoraxjnl-2012-202184

\section{ABSTRACT}

Background UK tuberculosis (TB) notifications are rising due to disease in the immigrant population. National screening guidelines have been revised but cost-effectiveness analyses are hampered by the lack of data on the comparative performance of tuberculin skin tests (TSTs) and interferon $\gamma$ release assays (IGRAs) in immigrants.

Methods Three-way evaluation of TSTs and two IGRAs (QuantiFERON Gold in-tube (QFN-GIT) and T-SPOT.TB) in immigrants aged $\geq 16$ years to quantify test positivity, concordance and factors associated with positivity. Yields were computed at different incidence thresholds and the relative cost-effectiveness of screening was estimated using different latent TB infection (LTBI) screening modalities at varying incidence thresholds with or without port-of-arrival chest $x$-ray (CXR).

Results 231 immigrants were included; median age 29 (IQR 24-37). TSTs were accepted by $80.9 \%$, read in 93.5\% and $30.3 \%$ were positive - QFN-GIT and TSPOT.TB positive in $16.6 \%$ and $22.5 \%$ respectively. Positive TSTs, QFN-GIT and T-SPOT.TB were independently associated with increasing TB incidence in immigrants' countries of origin ( $p=0.007,0.007,0.037$ respectively). Implementing current guidance (threshold $40 / 100000$ per year) would identify $98-100 \%$ of LTBIs (depending on test) but entail testing $97-99 \%$ of the cohort; screening at 150/100 000 per year would identify $49-71 \%$ of LTBIs but only entail screening half the cohort. The two most cost-effective screening strategies were no port-of-entry chest radiography and screen with single-step QFN-GIT at 250/100 000 per year (incremental cost-effectiveness ratio (ICER)) £21 565.3/case averted); and no port-of-entry CXR and screen with single-step QFN-GIT at 150/100 000 per year (averted additional 7.8 TB cases; ICER £31 867.1/ case averted).

Conclusions UK immigrant screening could costeffectively and safely eliminate mandatory CXR on arrival by emphasising systematic screening for LTBI with singlestep IGRA. Intermediate incidence thresholds balance the need to identify as many imported LTBls as possible against limited service capacity.

\section{INTRODUCTION}

To cite: Pareek $\mathrm{M}$, Bond $\mathrm{M}$, Shorey J, et al. Thorax

2013;68:230-239.
Tuberculosis (TB) is a public health concern in high-income, low-burden countries where historic

\section{Key messages}

What is the key question?

- What is the comparative performance, and cost effectiveness, of QuantiFERON Gold in-tube, T-SPOT.TB and tuberculin skin test, with and without chest $x$-ray (CXR), in the community-based diagnosis of latent tuberculosis (TB) in immigrants in the UK.

What is the bottom line?

- UK immigrant screening could cost effectively and safely eliminate mandatory CXR on arrival by emphasising systematic screening for latent TB with single-step interferon $\gamma$ release assay in the community. Intermediate screening incidence thresholds balance the need to identify as many cases of imported latent TB as possible against limited service capacity.

\section{Why read on?}

- Immigrant TB in developed countries makes up a significant proportion of cases, with most cases arising through the reactivation of latent TB acquired overseas prior to migration. This study is the first three-way comparison, and health economics analysis, of community-based immigrant screening for latent TB with QuantiFERON Gold in-tube, T-SPOT.TB and tuberculin skin test, with and without CXR.

reductions in notifications have slowed or reversed, resulting in $\mathrm{TB}$ becoming concentrated among foreign-born individuals. ${ }^{1}$ The UK has seen TB notifications increase continuously over the past 30 years; between 1998 and 2009 numbers rose by almost $50 \%$ to 9040 annual cases. Most of this increase has been among foreign-born individuals, in whom notifications have risen by $98 \% \%^{2}{ }^{3}$; foreign-born individuals now account for over $70 \%$ of UK TB notifications and have a 22-fold higher TB incidence (89 cases/100 000) than UK-born individuals (4 cases/100 000).

Underlying this disproportionate burden is the combination of reactivation of latent tuberculosis 
infection (LTBI), acquired prior to migration, and the high levels of migration from high TB burden nations in sub-Saharan Africa and the Indian subcontinent. ${ }^{4} 5$ This failure to control TB has reignited debate about immigrant screening. ${ }^{6}$

UK National Institute for Health and Clinical Excellence (NICE) recommendations from 2006 suggested that in addition to chest x-ray (CXR) at port of arrival, LTBI screening in adult immigrants should be restricted to adults from sub-Saharan Africa and other countries with TB incidence $>500 / 100000$, using a dual tuberculin skin test (TST) plus confirmatory interferon $\gamma$ release assay (IGRA) approach. ${ }^{7}$ However, there was a high level of non-adherence to these guidelines with many services using different screening thresholds and diagnostic tools. ${ }^{8}$ The health economics analysis underlying the guidelines was weakened by a lack of contemporary data on LTBI prevalence in immigrants, particularly when stratified by different TB incidence thresholds in countries of origin. This has been addressed by a recent UK study which found that screening at the levels that were suggested by NICE would miss most LTBI cases and that a reduced threshold would be more cost effective. ${ }^{9}$

Recently revised guidance now recommends adults from countries with TB incidence $>40 / 100000$ should be screened with TST plus IGRA or single-step IGRA. ${ }^{10}$ However, these guidelines continue to be based on scenarios rather than empirical screening data and thus are unable to definitively address key issues, such as which screening strategy is preferred (TST alone, TST plus IGRA or IGRA alone), which of the two commercial IGRAs (QuantiFERON-Gold in-tube (QFN-GIT), Cellestis, Carnegie, Australia and T-SPOT.TB, Oxford Immunotec, Oxford, UK) is more cost effective, and which, if any, incidence threshold may be most cost effective in diagnosing LTBI. In addition, the guidance provides little direction about the system of port-of-arrival CXRs to diagnose active TB which has been in place for over 40 years. The system's high costs and low yields for active disease ${ }^{11-13}$ underscore the need for a comprehensive assessment of its cost effectiveness.

We therefore undertook a prospective comparative assessment, in routine care, of TST and both available IGRAs as diagnostic tools for LTBI in new entrants with a specific focus on LTBI prevalence, how this varies by region of origin and the factors associated with LTBI. We also computed the cost effectiveness of LTBI screening using different screening modalities at different incidence thresholds in a primary care setting, with and without CXR screening on arrival at port of entry.

\section{METHODS}

\section{Study design and study centre}

This prospective assessment of immigrant screening was undertaken in Westminster (London, UK) which has an estimated population of 247000 people, of whom 53.0\% (95\% CI $52.8 \%$ to $53.2 \%$ ) are foreign born. ${ }^{14}$ Between 2007 and 2009, the 3-year average number of TB notifications per year in this area was 78 , while average TB incidence was 33 cases $(95 \% \mathrm{CI}$ 26 to 41 ) per 100000 population per year. ${ }^{15}$

\section{Study population and participants}

Between October 2008 and June 2010, all foreign-born immigrants registered with one of four participating primary care practices in Westminster were identified and referred to the newentrant screening service and, if eligible, were invited to participate in TB screening. Eligibility criteria for the study included foreign-born new entrants (arrival within preceding 5 years) aged $\geq 16$ years from all countries (if displaying symptoms of active TB) or from a country with a TB incidence of $\geq 40 / 100000$ (if asymptomatic). Country-specific TB incidence figures were based on 2007 WHO figures-the most current at the time the study commenced. Ethical approval was not required because the study utilised fully anonymised observational data collected as part of the routine delivery of a clinical service.

\section{Methods of screening}

Eligible immigrants were initially screened with a questionnaire which obtained information on demographics, country of origin, past history of $\mathrm{TB}$, history of $\mathrm{TB}$ contact, bacille Calmette Guérin (BCG) vaccination status (ascertained using scar, reliable history or documentary evidence $)^{16}$ and clinical symptoms of active TB. Following completion of the questionnaire, screening for LTBI was undertaken (see online supplementary information for details of IGRA and TST screening procedures and criteria for test positivity).

In accordance with UK national guidelines ${ }^{10}$ and routine clinical practice, during immigrant screening for LTBI we did not undertake HIV testing of subjects. Instead participants were asked to self-report previous HIV testing and if they knew if they were HIV seropositive.

\section{Management of symptomatic individuals and positive IGRAs}

Immigrants who were symptomatic at the initial screening visit and/or had a positive IGRA/TST result were referred for CXR and further clinical assessment to rule out active TB. ${ }^{7}$

For clinical decision-making purposes, immigrants with a positive IGRA (QFN-GIT or T.SPOT.TB) and/or positive TST and normal CXR in the absence of any clinical features suggestive of active TB were defined as having LTBI. $^{17}$ Immigrants diagnosed with LTBI aged $\leq 35$ years were offered chemoprophylaxis in accordance with UK guidelines. ${ }^{7}$

\section{Data analysis}

Details of the data analysis and health-economic modelling analysis, parameterised by empirical data drawn from the observational study, are presented in the online supplementary information (supplementary methods, supplementary tables 1-8 and supplementary figures 1-5).

\section{RESULTS}

\section{Description of the cohort}

Study recruitment is outlined in supplementary figure 6. A total of 231 subjects were included in the final analysis (table 1).

Screened immigrants were mainly young adults $(74.1 \%$, aged 16-35 years); $64.5 \%$ were women and $83.7 \%$ had previously been BCG vaccinated. Immigrants in this cohort most commonly originated from Asian countries (excluding the Indian subcontinent) (42.4\%) and the Indian subcontinent (21.2\%); $61.9 \%$ of the cohort had been resident in the UK for $\leq 2$ years.

There were no significant demographic differences between immigrants who were eligible, and screened, versus those who did not attend (table 1).

\section{Uptake and results of screening tests}

Supplementary figure 7 outlines the uptake of the three screening tools-TST, QFN-GIT and T-SPOT.TB.

Overall, if the stratified cut-off $(\geq 6 \mathrm{~mm}$ and $\geq 15 \mathrm{~mm}$ in BCG-unvaccinated and BCG-vaccinated individuals, respectively) for TST positivity was used, 53 of 175 immigrants (30.3\%, 95\% CI 23.6 to $37.7 \%)$ had a positive TST, whereas if the non-stratified cut-off $(\geq 10 \mathrm{~mm})$ was used, 66 of 175 (37.7\%, 95\% CI 30.5 to $45.3 \%)$ were deemed TST positive. There was no significant difference in size of induration 
Table 1 Demographic characteristics of immigrants screened in the study; selected characteristics (when data were available) are compared against those of immigrants who were not screened

\begin{tabular}{|c|c|c|c|}
\hline Variable & $\begin{array}{l}\text { Immigrants who were } \\
\text { screened }(n=231)\end{array}$ & $\begin{array}{l}\text { Immigrants who did } \\
\text { not attend }(\mathrm{n}=75)^{*}\end{array}$ & $\begin{array}{l}p \\
\text { Value }\end{array}$ \\
\hline \multicolumn{4}{|l|}{ Age categories (years) } \\
\hline $16-25$ & $87(37.7 \%)$ & $23(30.7 \%)$ & $0.39+$ \\
\hline $26-35$ & $84(36.4 \%)$ & $33(44.0 \%)$ & \\
\hline $36-45$ & $35(15.2 \%)$ & $14(18.7 \%)$ & \\
\hline Over 45 & $25(10.8 \%)$ & $5(6.7 \%)$ & \\
\hline \multicolumn{4}{|l|}{ Gender } \\
\hline Women & $149(64.5 \%)$ & $43(57.3 \%)$ & 0.27 \\
\hline Men & $82(35.5 \%)$ & $32(42.7 \%)$ & \\
\hline \multicolumn{4}{|l|}{ World region of origin $\ddagger$} \\
\hline $\begin{array}{l}\text { Europe, North } \\
\text { America }\end{array}$ & $16(6.9 \%)$ & $5(8.9 \%)$ & 0.57 \\
\hline South America & $14(6.1 \%)$ & $6(10.7 \%)$ & 0.24 \\
\hline Middle East & $19(8.2 \%)$ & $3(5.4 \%)$ & 0.59 \\
\hline Other Africa & $5(2.2 \%)$ & $3(5.3 \%)$ & 0.20 \\
\hline Other Asia & $98(42.4 \%)$ & $17(30.4 \%)$ & 0.13 \\
\hline Indian subcontinent & $49(21.2 \%)$ & $16(28.6 \%)$ & 0.29 \\
\hline Sub-Saharan Africa & $30(12.9 \%)$ & $6(10.7 \%)$ & 0.82 \\
\hline \multicolumn{4}{|c|}{ TB incidence in country of origin $\ddagger$} \\
\hline $0-65$ & $39(16.9 \%)$ & $11(19.6 \%)$ & 0.70 \\
\hline $66-170$ & $105(45.5 \%)$ & $33(58.9 \%)$ & 0.08 \\
\hline $171-300$ & $74(32.0 \%)$ & $11(19.6 \%)$ & 0.08 \\
\hline$>300$ & $13(5.6 \%)$ & $1(1.8 \%)$ & 0.32 \\
\hline \multicolumn{4}{|c|}{ Time since entry to the UK (years) } \\
\hline$<1$ & $38(15.6 \%)$ & & \\
\hline $1-2$ & $107(46.3 \%)$ & & \\
\hline $3-5$ & $88(38.1 \%)$ & & \\
\hline \multicolumn{4}{|l|}{ BCG vaccinated§ } \\
\hline No & $37(16.3 \%)$ & & \\
\hline Yes & $190(83.7 \%)$ & & \\
\hline \multicolumn{4}{|l|}{ History of TB contact } \\
\hline No & $216(94.3 \%)$ & & \\
\hline Yes & $13(5.7 \%)$ & & \\
\hline \multicolumn{4}{|c|}{ Travel to TB endemic country } \\
\hline No & $161(69.7 \%)$ & & \\
\hline Yes & $70(30.3 \%)$ & & \\
\hline \multicolumn{4}{|l|}{ Employed } \\
\hline Student & $66(28.6 \%)$ & & \\
\hline No/housewife & $66(28.6 \%)$ & & \\
\hline Yes & $99(28.6 \%)$ & & \\
\hline \multicolumn{4}{|c|}{ History of imprisonment } \\
\hline No & $228(98.7 \%)$ & & \\
\hline Yes & $3(1.3 \%)$ & & \\
\hline \multicolumn{4}{|l|}{ Previous HIV test ${ }^{* *}$} \\
\hline No & $139(60.2 \%)$ & & \\
\hline Yes & $85(36.8 \%)$ & & \\
\hline Unsure & $7(3.0 \%)$ & & \\
\hline \multicolumn{4}{|l|}{ Current smoker } \\
\hline No & $195(84.4 \%)$ & & \\
\hline Yes & $36(15.6 \%)$ & & \\
\hline \multicolumn{4}{|l|}{ Consumes alcohol } \\
\hline No & $169(73.2 \%)$ & & \\
\hline Yes & $62(26.8 \%)$ & & \\
\hline
\end{tabular}

* Selected characteristics (when data were available) are compared against those of immigrants who were not screened.

tp Value refers to overall comparison of age groups between immigrants who were screened and immigrants who did not attend.

fFor immigrants who were not screened, data on world region of origin and TB incidence in country of origin were available for 56 individuals.

$\S$ Data available for 227 individuals.

IData available for 229 individuals.

${ }^{*}$ *HIV testing was not undertaken in this study but no subjects self-reported

themselves as being HIV positive.

BCG, bacille Calmette Guérin; TB, tuberculosis. between BCG-vaccinated (median $7 \mathrm{~mm}$; IQR $0-15 \mathrm{~mm}$ ) and unvaccinated (median $6 \mathrm{~mm}$; IQR $0-10 \mathrm{~mm}$ ) individuals $(\mathrm{p}=0.51)$ (supplementary figure 8 and supplementary table 9 ).

Overall, with QFN-GIT, 38 of 229 individuals $(16.6 \%$, 95\% CI 12.0 to $22.1 \%)$ tested positive and $189(82.5 \%, 95 \%$ CI 77.0 to $87.2 \%)$ were negative; two subjects $(0.87 \%, 95 \%$ CI 0.1 to $3.1 \%$ ) had indeterminate results (supplementary figure 9). T-SPOT.TB results were available in $160(97.6 \%)$ immigrants. Thirty-six individuals $(22.5 \%, 95 \%$ CI 16.3 to $29.8 \%)$ were positive, 117 (73.1\%, 95\% CI 65.6 to $79.8 \%)$ were negative and 7 (4.4\%, 95\% CI 1.8 to $8.8 \%)$ individuals had an indeterminate result (supplementary figure 9).

Pairwise comparisons revealed that the proportion of immigrants positive by TST was significantly higher than QFN-GIT ( $p=0.0025$ for stratified TST cut-off, $p<0.0001$ for unstratified $10 \mathrm{~mm}$ TST cut-off) and T-SPOT.TB ( $\mathrm{p}=0.02$ for stratified TST cut-off, $\mathrm{p}<0.0001$ for unstratified $10 \mathrm{~mm}$ TST cut-off). In contrast, there was no difference in the proportion of immigrants positive by QFN-GIT and T-SPOT.TB $(\mathrm{p}=0.49)$. However, there was a significantly lower proportion of indeterminate results with QFN-GIT compared with T-SPOT.TB $(\mathrm{p}=0.02)$.

\section{Factors associated with positive screening test results}

Univariate and multivariate analyses of factors associated with TST and IGRA positivity in the immigrant cohort are shown in table 2. On multivariate analysis, for TST, QFN-GIT and T-SPOT.TB, increasing TB incidence in country of origin and increasing age were independently associated with positive screening test results (table 2).

\section{Concordance between screening tests and impact of prior BCG vaccination}

Supplementary results (supplementary informationConcordance between screening tests and impact of prior BCG vaccination), figure 1 and supplementary table 10 outline concordance between the different screening tools.

\section{Relationship between screening thresholds and screening test positivity}

Table 3 illustrates the outcomes of LTBI immigrant screening stratified by screening test and TB incidence in the migrants' countries of origin. For all three tests (TST, QFN-GIT and T-SPOT.TB) as the incidence threshold at which screening is instigated increases, fewer immigrants within the cohort are eligible to be screened; the number of individuals identified with a positive test result also decreases, although the proportion testing positive remains relatively constant. At each incidence threshold TST, in comparison to both IGRAs, identified a lower proportion of the total positives.

\section{Health economics analyses}

The numbers of cases of active TB, and the associated costs, for a hypothetical cohort of 10000 immigrants over the 20 -year time horizon of the health economics model are presented in table 4 with more detailed text in the supplementary results (supplementary information-health economics analysis).

Applying current UK national guidance (port-of-arrival CXR, screening with single-step IGRA or dual TST plus confirmatory IGRA at 40/100 000) would avert (compared with no screening) between 15.6 and 28.8 cases of active TB and incur additional costs of between $£ 594956.9$ and $£ 1530303.0$ over 20 years, depending on whether TST plus IGRA or IGRA alone was employed and which specific IGRA was utilised (QFN-GIT was less expensive and less effective than T-SPOT.TB). If 
Table 2 Univariate and multivariate analysis of factors associated with tuberculin skin test, QuantiFERON Gold in-tube and T-SPOT.TB positivity

\begin{tabular}{|c|c|c|c|c|c|c|c|c|c|c|c|c|}
\hline Variable & $\begin{array}{l}\text { No. TST positive/total } \\
\text { no. tested, } n=175\end{array}$ & $\begin{array}{l}\text { Unadjusted OR } \\
(95 \% \mathrm{Cl})\end{array}$ & $\begin{array}{l}\text { Adjusted OR* } \\
(95 \% \mathrm{Cl})\end{array}$ & $\mathrm{p}$ & $\begin{array}{l}\text { No. QFN-G-IT positive/total } \\
\text { no. tested, } n=229\end{array}$ & $\begin{array}{l}\text { Unadjusted OR } \\
(95 \% \mathrm{Cl})\end{array}$ & $\begin{array}{l}\text { Adjusted OR* } \\
(95 \% \mathrm{Cl})\end{array}$ & $\mathrm{p}$ & $\begin{array}{l}\text { No. T.SPOT.TB positive/ } \\
\text { total no. tested, } n=160\end{array}$ & $\begin{array}{l}\text { Unadjusted OR } \\
(95 \% \mathrm{Cl})\end{array}$ & $\begin{array}{l}\text { Adjusted OR* } \\
(95 \% \mathrm{Cl})\end{array}$ & $\mathrm{p}$ \\
\hline \multicolumn{13}{|l|}{ Age (years) } \\
\hline $16-25$ & $16 / 63(25.4 \%)$ & 1 & 1 & \multirow[t]{4}{*}{0.008} & $12 / 86(14.0 \%)$ & 1 & 1 & \multirow[t]{4}{*}{$0.003 \ddagger$} & $11 / 63(17.5 \%)$ & 1 & 1 & \multirow[t]{4}{*}{0.03} \\
\hline $26-35$ & $23 / 61(37.7 \%)$ & $\begin{array}{l}1.78(0.82 \text { to } \\
3.83)\end{array}$ & $\begin{array}{l}2.82(1.06 \text { to } \\
7.46)\end{array}$ & & 10/84 (11.9\%) & $\begin{array}{l}0.83(0.34 \text { to } \\
2.05)\end{array}$ & $\begin{array}{l}1.49(0.51 \text { to } \\
4.41)\end{array}$ & & $8 / 49(16.3 \%)$ & $\begin{array}{l}0.92(0.34 \text { to } \\
2.50)\end{array}$ & $\begin{array}{l}1.40(0.42 \text { to } \\
4.69)\end{array}$ & \\
\hline $36-45$ & $18 / 28(64.3 \%)$ & $\begin{array}{l}5.29(2.03 \text { to } \\
13.79)\end{array}$ & $\begin{array}{l}7.49(2.31 \text { to } \\
24.31)\end{array}$ & & $8 / 34(23.5 \%)$ & $\begin{array}{l}1.90(0.70 \text { to } \\
5.16)\end{array}$ & $\begin{array}{l}2.49(0.68 \text { to } \\
9.06)\end{array}$ & & $11 / 30(36.7 \%)$ & $\begin{array}{l}2.74(1.02 \text { to } \\
7.34)\end{array}$ & $\begin{array}{l}5.76(1.55 \text { to } \\
21.39)\end{array}$ & \\
\hline$>45$ & 9/23 (39.1\%) & $\begin{array}{l}1.89(0.69 \text { to } \\
5.19)\end{array}$ & $\begin{array}{l}4.51(1.22 \text { to } \\
16.69)\end{array}$ & & $8 / 25(32.0 \%)$ & $\begin{array}{l}2.90(1.03 \text { to } \\
8.20)\end{array}$ & $\begin{array}{l}6.23(1.47 \text { to } \\
26.33)\end{array}$ & & $6 / 18(33.3 \%)$ & $\begin{array}{l}2.36(0.73 \text { to } \\
7.66)\end{array}$ & $\begin{array}{l}3.54(0.72 \text { to } \\
17.33)\end{array}$ & \\
\hline \multicolumn{13}{|l|}{ Gender } \\
\hline Women & 33/106 (31.1\%) & 1 & 1 & \multirow[t]{8}{*}{0.19} & 23/147 (15.7\%) & 1 & 1 & \multirow[t]{8}{*}{0.72} & $22 / 105(21.0 \%)$ & 1 & 1 & \multirow[t]{8}{*}{0.33} \\
\hline Men & $33 / 69(22.4 \%)$ & $\begin{array}{l}2.03(1.08 \text { to } \\
3.79)\end{array}$ & $\begin{array}{l}1.71(0.77 \text { to } \\
3.79)\end{array}$ & & $15 / 82(18.3 \%)$ & $\begin{array}{l}1.21(0.59 \text { to } \\
2.47)\end{array}$ & $\begin{array}{l}1.19(0.46 \text { to } \\
3.06)\end{array}$ & & $14 / 55(25.5 \%)$ & $\begin{array}{l}1.29(0.60 \text { to } \\
2.78)\end{array}$ & $\begin{array}{l}0.59(0.20 \text { to } \\
1.72)\end{array}$ & \\
\hline \multicolumn{10}{|c|}{ World region of origint } & & & \\
\hline $\begin{array}{l}\text { Europe, } \\
\text { Americas }\end{array}$ & $3 / 56(11.5 \%)$ & 1 & & & $0 / 30(0.0 \%)$ & - & & & $1 / 16(6.3 \%)$ & 1 & & \\
\hline $\begin{array}{l}\text { Middle East, } \\
\text { North Africa }\end{array}$ & $7 / 19(36.8 \%)$ & $\begin{array}{l}4.47(0.98 \text { to } \\
20.49)\end{array}$ & & & $2 / 24(8.3 \%)$ & 1 & & & $2 / 12(16.7 \%)$ & $\begin{array}{l}3.00(0.24 \text { to } \\
37.67)\end{array}$ & & \\
\hline Other Asia & $36 / 78(46.2 \%)$ & $\begin{array}{l}6.57(1.82 \text { to } \\
23.70)\end{array}$ & & & $20 / 96(20.8 \%)$ & $\begin{array}{l}2.89(0.63 \text { to } \\
13.36)\end{array}$ & & & $20 / 71(28.2 \%)$ & $\begin{array}{l}5.88(0.73 \text { to } \\
47.52)\end{array}$ & & \\
\hline $\begin{array}{l}\text { Indian } \\
\text { subcontinent }\end{array}$ & $11 / 32(34.4 \%)$ & $\begin{array}{l}4.02(0.98 \text { to } \\
16.40)\end{array}$ & & & $7 / 49(14.3 \%)$ & $\begin{array}{l}1.83(0.35 \text { to } \\
9.58)\end{array}$ & & & $5 / 42(11.9 \%)$ & $\begin{array}{l}2.03 \text { ( } 0.22 \text { to } \\
18.84\end{array}$ & & \\
\hline $\begin{array}{l}\text { Sub-Saharan } \\
\text { Africa }\end{array}$ & $9 / 20(45.0 \%)$ & $\begin{array}{l}6.27(1.41 \text { to } \\
27.86)\end{array}$ & & & $9 / 30(30.0 \%)$ & $\begin{array}{l}4.71(0.91 \text { to } \\
24.42)\end{array}$ & & & $8 / 19(42.1 \%)$ & $\begin{array}{l}10.91(1.19 \text { to } \\
100.41)\end{array}$ & & \\
\hline \multicolumn{13}{|c|}{ TB incidence in country of origin (per 100000 p.a.) $\dagger$} \\
\hline$\leq 65$ & $6 / 30(20.0 \%)$ & 1 & 1 & \multirow[t]{4}{*}{0.007} & $2 / 39(5.1 \%)$ & 1 & 1 & \multirow[t]{4}{*}{0.007} & $2 / 18(11.1 \%)$ & 1 & $\begin{array}{l}1.75(0.31 \text { to } \\
9.84)\end{array}$ & \multirow[t]{4}{*}{0.037} \\
\hline $66-170$ & $31 / 84(36.9 \%)$ & $\begin{array}{l}2.34(0.86 \text { to } \\
6.35)\end{array}$ & $\begin{array}{l}4.50(1.44 \text { to } \\
14.07)\end{array}$ & & 12/103 (11.7\%) & $\begin{array}{l}2.44(0.52 \text { to } \\
11.44)\end{array}$ & $\begin{array}{l}3.58(0.69 \text { to } \\
18.62)\end{array}$ & & $12 / 73(16.4 \%)$ & $\begin{array}{l}1.57(0.32 \text { to } \\
7.76)\end{array}$ & $\begin{array}{l}6.28(1.07 \text { to } \\
36.92)\end{array}$ & \\
\hline $171-300$ & $27 / 56(48.2 \%)$ & $\begin{array}{l}3.72(1.32 \text { to } \\
10.5)\end{array}$ & $\begin{array}{l}10.29(2.79 \text { to } \\
37.97)\end{array}$ & & $22 / 74(29.7 \%)$ & $\begin{array}{l}7.83(1.73 \text { to } \\
35.35)\end{array}$ & $\begin{array}{l}13.92(2.48 \text { to } \\
78.07)\end{array}$ & & $19 / 63(30.2 \%)$ & $\begin{array}{l}3.45(0.72 \text { to } \\
16.53)\end{array}$ & & \\
\hline$>300$ & $2 / 5(40.0 \%)$ & $\begin{array}{l}2.67(0.36 \text { to } \\
19.71)\end{array}$ & $\begin{array}{l}5.95(0.61 \text { to } \\
58.18)\end{array}$ & & $2 / 13(15.4 \%)$ & $\begin{array}{l}3.36(0.42 \text { to } \\
26.72)\end{array}$ & $\begin{array}{l}8.07(0.82 \text { to } \\
79.49)\end{array}$ & & $3 / 6(50.0 \%)$ & $\begin{array}{l}8.00(0.91 \text { to } \\
70.27)\end{array}$ & $\begin{array}{l}9.64(0.77 \text { to } \\
121.31)\end{array}$ & \\
\hline \multicolumn{13}{|c|}{ Time since arrival in the UK (years) } \\
\hline$<1$ & $10 / 25(40.0 \%)$ & 1 & 1 & \multirow[t]{3}{*}{0.11} & $5 / 36(13.9 \%)$ & 1 & 1 & \multirow[t]{3}{*}{0.88} & $5 / 13(38.5 \%)$ & 1 & 1 & \multirow[t]{3}{*}{0.09} \\
\hline $1-2$ & $35 / 89(39.3 \%)$ & $\begin{array}{l}0.97(0.39 \text { to } \\
2.41)\end{array}$ & $\begin{array}{l}0.89(0.31 \text { to } \\
2.56)\end{array}$ & & 15/105 (14.3\%) & $\begin{array}{l}1.03(0.35 \text { to } \\
3.08)\end{array}$ & $\begin{array}{l}0.80 \text { ( } 0.23 \text { to } \\
2.84)\end{array}$ & & $16 / 81(19.8 \%)$ & $\begin{array}{l}0.39(0.11 \text { to } \\
1.37)\end{array}$ & $\begin{array}{l}0.22(0.05 \text { to } \\
1.00)\end{array}$ & \\
\hline $3-5$ & 21/61 (34.4\%) & $\begin{array}{l}0.79(0.30 \text { to } \\
2.05)\end{array}$ & $\begin{array}{l}0.37 \text { ( } 0.12 \text { to } \\
1.20)\end{array}$ & & $18 / 88(20.5 \%)$ & $\begin{array}{l}1.59(0.54 \text { to } \\
4.68)\end{array}$ & $\begin{array}{l}0.98(0.27 \text { to } \\
3.59)\end{array}$ & & $15 / 66(22.7 \%)$ & $\begin{array}{l}0.47(0.13 \text { to } \\
1.65)\end{array}$ & $\begin{array}{l}0.17(0.03 \text { to } \\
0.85)\end{array}$ & \\
\hline \multicolumn{13}{|l|}{ BCG vaccinated } \\
\hline No & $8 / 29(27.6 \%)$ & 1 & 1 & \multirow[t]{2}{*}{0.40} & $7 / 37(18.9 \%)$ & 1 & 1 & \multirow[t]{2}{*}{0.75} & $4 / 25(16.0 \%)$ & 1 & 1 & \multirow[t]{2}{*}{0.57} \\
\hline Yes & $57 / 143(39.9 \%)$ & $\begin{array}{l}1.74(0.72 \text { to } \\
4.20)\end{array}$ & $\begin{array}{l}1.56 \text { (0.56 to } \\
4.33 \text { ) }\end{array}$ & & 30/188 (16.0\%) & $\begin{array}{l}0.81(0.33 \text { to } \\
2.02)\end{array}$ & $\begin{array}{l}0.84(0.30 \text { to } \\
2.40)\end{array}$ & & $31 / 132(23.5 \%)$ & $\begin{array}{l}1.61(0.51 \text { to } \\
5.05)\end{array}$ & $\begin{array}{l}1.46(0.40 \text { to } \\
5.28)\end{array}$ & \\
\hline
\end{tabular}


Table 2 Continued

\begin{tabular}{|c|c|c|c|c|c|c|c|c|c|c|c|c|}
\hline Variable & $\begin{array}{l}\text { No. TST positive/total } \\
\text { no. tested, } n=175\end{array}$ & $\begin{array}{l}\text { Unadjusted OR } \\
(95 \% \mathrm{Cl})\end{array}$ & $\begin{array}{l}\text { Adjusted OR* } \\
(95 \% \mathrm{Cl})\end{array}$ & $\mathrm{p}$ & $\begin{array}{l}\text { No. QFN-G-IT positive/total } \\
\text { no. tested, } n=229\end{array}$ & $\begin{array}{l}\text { Unadjusted OR } \\
(95 \% \mathrm{Cl})\end{array}$ & $\begin{array}{l}\text { Adjusted OR* } \\
(95 \% \mathrm{Cl})\end{array}$ & $\mathrm{p}$ & $\begin{array}{l}\text { No. T.SPOT.TB positive/ } \\
\text { total no. tested, } n=160\end{array}$ & $\begin{array}{l}\text { Unadjusted OR } \\
(95 \% \mathrm{Cl})\end{array}$ & $\begin{array}{l}\text { Adjusted OR* } \\
(95 \% \mathrm{Cl})\end{array}$ & $\mathrm{p}$ \\
\hline \multicolumn{13}{|c|}{ Travel to $T B$ endemic country } \\
\hline No & $41 / 121(33.9 \%)$ & 1 & 1 & \multirow[t]{2}{*}{0.18} & $21 / 159(13.2 \%)$ & 1 & 1 & \multirow[t]{2}{*}{0.06} & 21/111 (18.9\%) & 1 & 1 & \multirow[t]{2}{*}{0.08} \\
\hline Yes & $25 / 54(46.3 \%)$ & $\begin{array}{l}1.68(0.87 \text { to } \\
3.24)\end{array}$ & $\begin{array}{l}1.77(0.77 \text { to } \\
4.06)\end{array}$ & & $17 / 70(24.3 \%)$ & $\begin{array}{l}2.11 \text { (1.03 to } \\
4.30)\end{array}$ & $\begin{array}{l}2.25(0.96 \text { to } \\
5.26)\end{array}$ & & $15 / 49(30.6 \%)$ & $\begin{array}{l}1.89(0.87 \text { to } \\
4.09)\end{array}$ & $\begin{array}{l}2.37(0.90 \text { to } \\
6.28)\end{array}$ & \\
\hline \multicolumn{13}{|l|}{ TB contact } \\
\hline No & $60 / 164(36.6 \%)$ & 1 & 1 & \multirow[t]{2}{*}{0.23} & $33 / 215(15.4 \%)$ & 1 & 1 & \multirow[t]{2}{*}{0.14} & $31 / 148(21.0 \%)$ & 1 & 1 & \multirow[t]{2}{*}{0.07} \\
\hline Yes & $6 / 9(66.7 \%)$ & $\begin{array}{l}3.47(0.84 \text { to } \\
14.36)\end{array}$ & $\begin{array}{l}2.71(0.53 \text { to } \\
13.82)\end{array}$ & & $5 / 13(38.5 \%)$ & $\begin{array}{l}3.44 \text { (1.06 to } \\
11.19)\end{array}$ & $\begin{array}{l}2.93(0.72 \text { to } \\
12.01)\end{array}$ & & $5 / 11(45.5 \%)$ & $\begin{array}{l}3.15(0.9 \text { to } \\
10.99)\end{array}$ & $\begin{array}{l}4.01 \text { ( } 0.92 \text { to } \\
17.48)\end{array}$ & \\
\hline \multicolumn{13}{|c|}{ Employment status } \\
\hline Unemployed & $18 / 51(35.3 \%)$ & 1 & 1 & \multirow[t]{3}{*}{0.55} & 15/65 (23.1\%) & 1 & 1 & \multirow[t]{3}{*}{0.25} & $11 / 53(20.8 \%)$ & 1 & 1 & \multirow[t]{3}{*}{0.10} \\
\hline Employed & $27 / 70(38.6 \%)$ & $\begin{array}{l}1.15(0.54 \text { to } \\
2.44)\end{array}$ & $\begin{array}{l}0.92 \text { (0.36 to } \\
2.37)\end{array}$ & & $13 / 99(13.1 \%)$ & $\begin{array}{l}0.50(0.22 \text { to } \\
1.14)\end{array}$ & $\begin{array}{l}0.46 \text { (0.16 to } \\
1.3)\end{array}$ & & $14 / 63(22.2 \%)$ & $\begin{array}{l}1.09(0.45 \text { to } \\
2.66)\end{array}$ & $\begin{array}{l}0.96(0.31 \text { to } \\
2.98)\end{array}$ & \\
\hline Student & $21 / 54(38.9 \%)$ & $\begin{array}{l}1.20(0.50 \text { to } \\
2.60)\end{array}$ & $\begin{array}{l}1.49(0.58 \text { to } \\
3.83)\end{array}$ & & $10 / 65(15.4 \%)$ & $\begin{array}{l}0.61 \text { ( } 0.25 \text { to } \\
1.47)\end{array}$ & $\begin{array}{l}1.06(0.36 \text { to } \\
3.1)\end{array}$ & & $11 / 44(25.0 \%)$ & $\begin{array}{l}1.27(0.49 \text { to } \\
3.30)\end{array}$ & $\begin{array}{l}3.13(0.94 \text { to } \\
10.4)\end{array}$ & \\
\hline \multicolumn{13}{|l|}{ Alcohol } \\
\hline No & $48 / 131(36.6 \%)$ & 1 & 1 & \multirow[t]{2}{*}{0.79} & 30/167 (18.0\%) & 1 & 1 & \multirow[t]{2}{*}{0.97} & $27 / 126(21.4 \%)$ & 1 & 1 & \multirow[t]{2}{*}{0.10} \\
\hline Yes & $18 / 44(40.9 \%)$ & $\begin{array}{l}1.20 \text { (0.60 to } \\
2.41)\end{array}$ & $\begin{array}{l}1.13(0.46 \text { to } \\
2.78)\end{array}$ & & $8 / 62(12.9 \%)$ & $\begin{array}{l}0.68(0.29 \text { to } \\
1.57)\end{array}$ & $\begin{array}{l}1.02(0.35 \text { to } \\
3.02)\end{array}$ & & $9 / 34(26.5 \%)$ & $\begin{array}{l}1.32(0.55 \text { to } \\
3.16)\end{array}$ & $\begin{array}{l}2.78(0.83 \text { to } \\
9.23)\end{array}$ & \\
\hline \multicolumn{13}{|l|}{ Smoker } \\
\hline No & $56 / 146(38.4 \%)$ & 1 & 1 & \multirow[t]{2}{*}{0.73} & $34 / 193(17.6 \%)$ & 1 & 1 & \multirow[t]{2}{*}{0.75} & $33 / 136(24.3 \%)$ & 1 & 1 & \multirow[t]{2}{*}{0.75} \\
\hline Yes & $10 / 29(34.5 \%)$ & $\begin{array}{l}0.85 \text { ( } 0.37 \text { to } \\
1.95)\end{array}$ & $\begin{array}{l}1.21 \text { (0.41 to } \\
3.58)\end{array}$ & & 4/36 (11.1\%) & $\begin{array}{l}0.58 \text { (0.19 to } \\
1.76)\end{array}$ & $\begin{array}{l}1.25 \text { ( } 0.32 \text { to } \\
4.80)\end{array}$ & & $3 / 24(12.5 \%)$ & $\begin{array}{l}0.45 \text { ( } 0.13 \text { to } \\
1.59)\end{array}$ & $\begin{array}{l}0.77 \text { ( } 0.15 \text { to } \\
3.88)\end{array}$ & \\
\hline \multicolumn{13}{|c|}{ History of imprisonment } \\
\hline No & $65 / 172(37.8 \%)$ & 1 & 1 & \multirow[t]{2}{*}{0.83} & $38 / 226(16.8 \%)$ & & & & $35 / 157(22.3 \%)$ & 1 & 1 & \multirow[t]{2}{*}{0.16} \\
\hline Yes & $1 / 3(33.3 \%)$ & $\begin{array}{l}0.82(0.07 \text { to } \\
9.26)\end{array}$ & $\begin{array}{l}1.34(0.09 \text { to } \\
19.49)\end{array}$ & & $0 / 3(0.0 \%)$ & & & & $1 / 3(33.3 \%)$ & $\begin{array}{l}1.74(0.15 \text { to } \\
19.79)\end{array}$ & $\begin{array}{l}7.79(0.46 \text { to } \\
132.76)\end{array}$ & \\
\hline
\end{tabular}




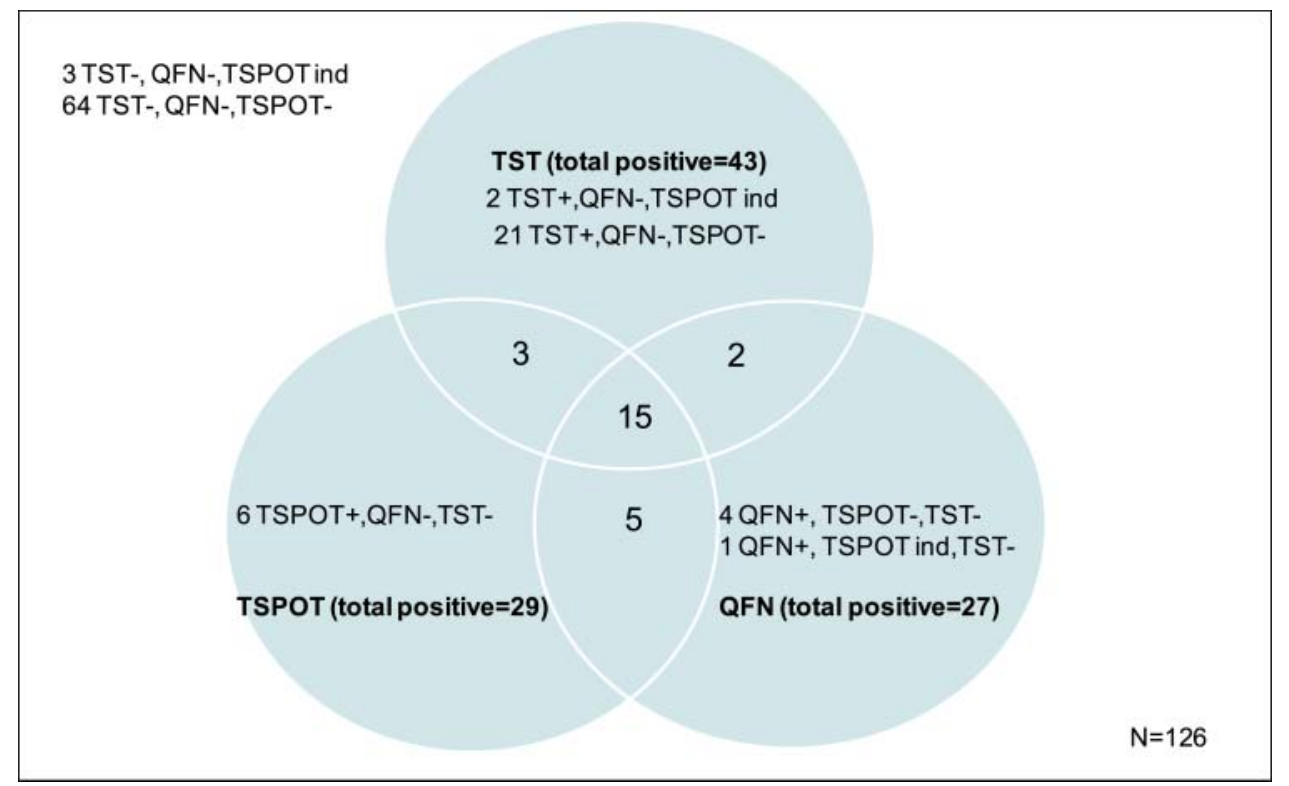

Figure 1 Venn diagram showing test results where all three screening tests were undertaken. Ind, indeterminate; QFN, QuantiFERON; TST, tuberculin skin test.

port-of-arrival CXR screening was removed from national policy then savings of almost $£ 100000$ would be made over 20 years with little impact on the number of TB cases averted. Increasing the screening threshold (eg, to 150/100 000-the Indian subcontinent) but keeping port-of-arrival CXR and using the identical screening tools would avert $58-66 \%$ of cases and incur $55-65 \%$ of costs compared with screening at 40/100 000 .

With dominated options excluded (table 4) five cost-effective strategies remained which, in decreasing order of cost effectiveness, were no port-of-arrival CXR and single-step QFN-GIT at 250/100 000; no port-of-arrival CXR and single-step QFN-GIT at 150/100 000; no port-of-entry CXR and single-step QFN-GIT at 40/100 000; CXR at port-of-arrival and single-step QFN-GIT at 40/100 000; and, finally, CXR at port-of-arrival and single-step T-SPOT.TB at 40/100 000. The associated incremental cost-effectiveness ratios for these strategies were $£ 21$ 565.3, £31 867.1, £34 753.5, £59489.1 and £402421.8 respectively per active TB case averted. The results remained unchanged when analyses were restricted to individuals tested concurrently with all three diagnostic modalities.

The results of the univariate sensitivity analysis are presented in online supplementary tables 11 and 12 with more detailed text in the supplementary results (supplementary informationSensitivity analysis).

\section{DISCUSSION}

This is the first three-way assessment of different screening methods for LTBI in recent immigrants which provides comparative estimates of test performance and positivity stratified by demographic factors and risk factors for LTBI. Consequently we have been able to evaluate, using a decision-analysis model, the cost effectiveness of screening with port-of-arrival CXRs and for LTBI. Our analysis reveals that UK policy could be modified by removing the current requirement for CXR on arrival and concentrating on LTBI testing using single-step IGRA testing targeted at adult immigrants arriving from countries with moderate TB incidence (rather than from countries with TB incidence $>40 / 100000$ as recommended currently). ${ }^{10}$

In this cohort the proportion positive by TST $(30.3 \% ; 36.7 \%$ with $10 \mathrm{~mm}$ cut-off) was significantly higher than with QFN-GIT (16.6\%) or T-SPOT.TB (22.5\%). Previous studies have assessed LTBI prevalence in immigrants with TST and found that positivity varies from $26 \%$ to $72 \%$ depending on the setting, type of migrants studied (legal or undocumented immigrants),

Table 3 Yields for test positivity by different screening tests at different screening thresholds

\begin{tabular}{|c|c|c|c|c|c|c|c|c|c|c|c|c|}
\hline \multirow{2}{*}{$\begin{array}{l}\text { TB incidence screening threshold } \\
\text { (/100 } 000 \text { per year) }\end{array}$} & \multicolumn{3}{|c|}{ No. tested } & \multicolumn{3}{|c|}{ No. positive } & \multicolumn{3}{|c|}{$\begin{array}{l}\text { Yield at incidence level, } \\
\text { that is, proportion of } \\
\text { those tested }\end{array}$} & \multicolumn{3}{|c|}{$\begin{array}{l}\text { Positives identified if } \\
\text { threshold set at this level } \\
(\%)\end{array}$} \\
\hline & TST & QFN & TSPOT & TST & QFN & TSPOT & TST & QFN & TSPOT & TST & QFN & TSPOT \\
\hline Screen $\geq 350$ & 4 & 11 & 4 & 1 & 1 & 1 & 25.0 & 9.1 & 25.0 & 1.9 & 2.6 & 2.8 \\
\hline Screen $\geq 300$ & 5 & 13 & 6 & 1 & 2 & 3 & 20.0 & 15.4 & 50.0 & 1.9 & 5.3 & 8.3 \\
\hline Screen $\geq 250$ & 23 & 37 & 28 & 10 & 13 & 12 & 43.5 & 35.1 & 42.9 & 18.9 & 34.2 & 33.3 \\
\hline Screen $\geq 200$ & 50 & 75 & 59 & 20 & 19 & 17 & 40.0 & 25.3 & 28.8 & 37.7 & 50.0 & 47.2 \\
\hline Screen $\geq 150$ & 71 & 105 & 84 & 26 & 27 & 25 & 36.6 & 25.7 & 29.8 & 49.1 & 71.1 & 69.4 \\
\hline Screen $\geq 100$ & 104 & 143 & 110 & 30 & 29 & 28 & 28.9 & 20.3 & 25.5 & 56.6 & 76.3 & 77.8 \\
\hline Screen $\geq 40^{*}$ & 170 & 222 & 158 & 52 & 38 & 36 & 30.6 & 17.1 & 22.8 & 98.1 & 100.0 & 100.0 \\
\hline Screen all & 175 & 229 & 160 & 53 & 38 & 36 & 30.3 & 16.6 & 22.5 & 100.0 & 100.0 & 100.0 \\
\hline
\end{tabular}

*Current threshold recommended by National Institute for Health and Clinical Excellence guidance is given in bold text.

QFN, QuantiFERON Gold in-tube; TB, tuberculosis; TST, tuberculin skin test. 
Table 4 Projected cases of active tuberculosis (TB) and associated costs arising from undertaking immigrant screening using different screening tools at different screening thresholds (arranged in order of increasing effectiveness-ie, fewer cases of active TB) for a hypothetical cohort of 10000 immigrants over a 20-year time horizon

\begin{tabular}{|c|c|c|c|c|c|c|c|}
\hline \multirow[b]{2}{*}{$\begin{array}{l}\text { CXR at } \\
\text { port of } \\
\text { arrival }\end{array}$} & \multicolumn{2}{|l|}{ Screening for LTBI } & \multirow[b]{2}{*}{$\begin{array}{l}\text { Cases of } \\
\text { active TB } \\
\text { (over } \\
20 \text { years) }\end{array}$} & \multirow[b]{2}{*}{$\begin{array}{l}\text { Costs } \\
(\mathrm{f}, 2010)\end{array}$} & \multirow[b]{2}{*}{$\begin{array}{l}\text { Incremental cases } \\
\text { of active TB }\end{array}$} & \multirow[b]{2}{*}{$\begin{array}{l}\text { Incremental costs } \\
(\mathrm{f}, \mathbf{2 0 1 0})\end{array}$} & \multirow[b]{2}{*}{ ICER } \\
\hline & Screening tool & $\begin{array}{l}\text { Screening } \\
\text { threshold } \\
\text { for immigrants } \\
\text { (cases of } \\
\text { TB/100 } 000 \\
\text { per year) }\end{array}$ & & & & & \\
\hline No & None & None & 100.5 & 659609.4 & Baseline & Baseline & Baseline \\
\hline No & TST plus QFN & 350 & 100.4 & 690521.6 & $\begin{array}{l}\text { Extended } \\
\text { dominance }\end{array}$ & Extended dominance & $\begin{array}{l}\text { Extended } \\
\text { dominance }\end{array}$ \\
\hline No & TST plus T-SPOT.TB & 350 & 100.3 & 696433.4 & $\begin{array}{l}\text { Extended } \\
\text { dominance }\end{array}$ & Extended dominance & $\begin{array}{l}\text { Extended } \\
\text { dominance }\end{array}$ \\
\hline No & TST & 350 & 100.1 & 706478.7 & Strict dominance & Strict dominance & Strict dominance \\
\hline No & TST plus QFN & 300 & 100.0 & 707756.2 & Strict dominance & Strict dominance & Strict dominance \\
\hline No & TST plus T-SPOT.TB & 300 & 99.8 & 715317.0 & Strict dominance & Strict dominance & Strict dominance \\
\hline No & QFN & 350 & 99.4 & 701675.9 & $\begin{array}{l}\text { Extended } \\
\text { dominance }\end{array}$ & Extended dominance & $\begin{array}{l}\text { Extended } \\
\text { dominance }\end{array}$ \\
\hline No & TST & 300 & 99.4 & 721759.0 & $\begin{array}{l}\text { Extended } \\
\text { dominance }\end{array}$ & Extended dominance & $\begin{array}{l}\text { Extended } \\
\text { dominance }\end{array}$ \\
\hline No & T-SPOT.TB & 350 & 99.3 & 728560.7 & Strict dominance & Strict dominance & Strict dominance \\
\hline Yes & None & None & 98.9 & 754339.9 & Strict dominance & Strict dominance & Strict dominance \\
\hline Yes & TST plus QFN & 350 & 98.8 & 785252.0 & Strict dominance & Strict dominance & Strict dominance \\
\hline Yes & TST plus T-SPOT.TB & 350 & 98.7 & 791163.9 & Strict dominance & Strict dominance & Strict dominance \\
\hline Yes & TST & 350 & 98.5 & 801209.1 & Strict dominance & Strict dominance & Strict dominance \\
\hline Yes & TST plus QFN & 300 & 98.4 & 802486.6 & Strict dominance & Strict dominance & Strict dominance \\
\hline Yes & TST plus T-SPOT.TB & 300 & 98.2 & 810047.5 & Strict dominance & Strict dominance & Strict dominance \\
\hline No & QFN & 300 & 98.0 & 723513.2 & $\begin{array}{l}\text { Extended } \\
\text { dominance }\end{array}$ & Extended dominance & $\begin{array}{l}\text { Extended } \\
\text { dominance }\end{array}$ \\
\hline Yes & QFN & 350 & 97.8 & 796406.3 & Strict dominance & Strict dominance & Strict dominance \\
\hline Yes & TST & 300 & 97.8 & 816489.4 & Strict dominance & Strict dominance & Strict dominance \\
\hline No & TST plus QFN & 250 & 97.8 & 793192.7 & Strict dominance & Strict dominance & Strict dominance \\
\hline No & T-SPOT.TB & 300 & 97.7 & 751926.8 & $\begin{array}{l}\text { Extended } \\
\text { dominance }\end{array}$ & Extended dominance & $\begin{array}{l}\text { Extended } \\
\text { dominance }\end{array}$ \\
\hline Yes & T-SPOT.TB & 350 & 97.7 & 823291.1 & Strict dominance & Strict dominance & Strict dominance \\
\hline No & TST plus T-SPOT.TB & 250 & 97.3 & 813690.1 & $\begin{array}{l}\text { Extended } \\
\text { dominance }\end{array}$ & Extended dominance & $\begin{array}{l}\text { Extended } \\
\text { dominance }\end{array}$ \\
\hline Yes & QFN & 300 & 96.4 & 818243.7 & $\begin{array}{l}\text { Extended } \\
\text { dominance }\end{array}$ & Extended dominance & $\begin{array}{l}\text { Extended } \\
\text { dominance }\end{array}$ \\
\hline Yes & TST plus QFN & 250 & 96.2 & 887923.2 & Strict dominance & Strict dominance & Strict dominance \\
\hline No & TST & 250 & 96.2 & 823749.7 & $\begin{array}{l}\text { Extended } \\
\text { dominance }\end{array}$ & Extended dominance & $\begin{array}{l}\text { Extended } \\
\text { dominance }\end{array}$ \\
\hline Yes & T-SPOT.TB & 300 & 96.1 & 846657.3 & Strict dominance & Strict dominance & Strict dominance \\
\hline Yes & TST plus T-SPOT.TB & 250 & 95.7 & 908420.5 & Strict dominance & Strict dominance & Strict dominance \\
\hline No & TST plus QFN & 200 & 95.6 & 867394.4 & Strict dominance & Strict dominance & Strict dominance \\
\hline No & TST plus T-SPOT.TB & 200 & 95.0 & 913943.4 & Strict dominance & Strict dominance & Strict dominance \\
\hline Yes & TST & 250 & 94.6 & 918480.1 & Strict dominance & Strict dominance & Strict dominance \\
\hline Yes & TST plus QFN & 200 & 94.0 & 962124.9 & Strict dominance & Strict dominance & Strict dominance \\
\hline No & TST & 200 & 93.8 & 995462.9 & Strict dominance & Strict dominance & Strict dominance \\
\hline Yes & TST plus T-SPOT.TB & 200 & 93.4 & 1008673.9 & Strict dominance & Strict dominance & Strict dominance \\
\hline No & TST plus QFN & 150 & 93.0 & 954636.7 & Strict dominance & Strict dominance & Strict dominance \\
\hline No & TST plus T-SPOT.TB & 150 & 92.3 & 1023409.3 & Strict dominance & Strict dominance & Strict dominance \\
\hline Yes & TST & 200 & 92.2 & 1090193.4 & Strict dominance & Strict dominance & Strict dominance \\
\hline No & QFN & 250 & 92.1 & 839713.7 & 8.4 & 180104.3 & 21565.3 \\
\hline No & TST plus QFN & 100 & 91.5 & 1018843.7 & Strict dominance & Strict dominance & Strict dominance \\
\hline Yes & TST plus QFN & 150 & 91.4 & 1049367.2 & Strict dominance & Strict dominance & Strict dominance \\
\hline No & T-SPOT.TB & 250 & 91.3 & 909426.7 & $\begin{array}{l}\text { Extended } \\
\text { dominance }\end{array}$ & Extended dominance & $\begin{array}{l}\text { Extended } \\
\text { dominance }\end{array}$ \\
\hline No & TST plus T-SPOT.TB & 100 & 90.7 & 1113644.2 & Strict dominance & Strict dominance & Strict dominance \\
\hline Yes & TST plus T-SPOT.TB & 150 & 90.7 & 1118139.7 & Strict dominance & Strict dominance & Strict dominance \\
\hline No & TST & 150 & 90.6 & 1149671.8 & Strict dominance & Strict dominance & Strict dominance \\
\hline
\end{tabular}


Table 4 Continued

\begin{tabular}{|c|c|c|c|c|c|c|c|}
\hline \multirow[b]{2}{*}{$\begin{array}{l}\text { CXR at } \\
\text { port of } \\
\text { arrival }\end{array}$} & \multicolumn{2}{|l|}{ Screening for LTBI } & \multirow[b]{2}{*}{$\begin{array}{l}\text { Cases of } \\
\text { active TB } \\
\text { (over } \\
20 \text { years) }\end{array}$} & \multirow[b]{2}{*}{$\begin{array}{l}\text { Costs } \\
(f, 2010)\end{array}$} & \multirow[b]{2}{*}{$\begin{array}{l}\text { Incremental cases } \\
\text { of active TB }\end{array}$} & \multirow[b]{2}{*}{$\begin{array}{l}\text { Incremental costs } \\
(\mathrm{f}, 2010)\end{array}$} & \multirow[b]{2}{*}{ ICER } \\
\hline & Screening tool & $\begin{array}{l}\text { Screening } \\
\text { threshold } \\
\text { for immigrants } \\
\text { (cases of } \\
\text { TB/100 } 000 \\
\text { per year) }\end{array}$ & & & & & \\
\hline Yes & QFN & 250 & 90.6 & 934444.2 & $\begin{array}{l}\text { Extended } \\
\text { dominance }\end{array}$ & Extended dominance & $\begin{array}{l}\text { Extended } \\
\text { dominance }\end{array}$ \\
\hline Yes & TST plus QFN & 100 & 89.9 & 1113574.1 & Strict dominance & Strict dominance & Strict dominance \\
\hline Yes & T-SPOT.TB & 250 & 89.7 & 1004157.2 & Strict dominance & Strict dominance & Strict dominance \\
\hline No & QFN & 200 & 89.1 & 959014.5 & $\begin{array}{l}\text { Extended } \\
\text { dominance }\end{array}$ & Extended dominance & $\begin{array}{l}\text { Extended } \\
\text { dominance }\end{array}$ \\
\hline Yes & TST plus T-SPOT.TB & 100 & 89.1 & 1208374.6 & Strict dominance & Strict dominance & Strict dominance \\
\hline No & TST & 100 & 89.0 & 1319841.4 & Strict dominance & Strict dominance & Strict dominance \\
\hline Yes & TST & 150 & 89.0 & 1244402.3 & Strict dominance & Strict dominance & Strict dominance \\
\hline No & T-SPOT.TB & 200 & 88.2 & 1171831.5 & Strict dominance & Strict dominance & Strict dominance \\
\hline Yes & QFN & 200 & 87.6 & 1053744.9 & $\begin{array}{l}\text { Extended } \\
\text { dominance }\end{array}$ & Extended dominance & $\begin{array}{l}\text { Extended } \\
\text { dominance }\end{array}$ \\
\hline Yes & TST & 100 & 87.4 & 1414571.9 & Strict dominance & Strict dominance & Strict dominance \\
\hline Yes & T-SPOT.TB & 200 & 86.6 & 1266562.0 & Strict dominance & Strict dominance & Strict dominance \\
\hline No & TST plus QFN & 40 & 86.5 & 1159835.9 & Strict dominance & Strict dominance & Strict dominance \\
\hline No & TST plus T-SPOT.TB & 40 & 85.5 & 1296089.2 & Strict dominance & Strict dominance & Strict dominance \\
\hline Yes & TST plus QFN & 40 & 84.9 & 1254566.3 & Strict dominance & Strict dominance & Strict dominance \\
\hline No & QFN & 150 & 84.3 & 1089176.5 & 7.8 & 249462.8 & 31867.1 \\
\hline Yes & $\begin{array}{l}\text { TST plus T-SPOT. } \\
\text { TB }\end{array}$ & 40 & 83.9 & 1390819.6 & Strict dominance & Strict dominance & Strict dominance \\
\hline No & TST & 40 & 83.3 & 1597273.1 & Strict dominance & Strict dominance & Strict dominance \\
\hline No & T-SPOT.TB & 150 & 83.0 & 1408873.0 & Strict dominance & Strict dominance & Strict dominance \\
\hline No & QFN & 100 & 82.8 & 1195634.0 & Strict dominance & Strict dominance & Strict dominance \\
\hline Yes & QFN & 150 & 82.7 & 1183906.9 & $\begin{array}{l}\text { Extended } \\
\text { dominance }\end{array}$ & Extended dominance & $\begin{array}{l}\text { Extended } \\
\text { dominance }\end{array}$ \\
\hline Yes & TST & 40 & 81.7 & 1692003.5 & Strict dominance & Strict dominance & Strict dominance \\
\hline No & T-SPOT.TB & 100 & 81.5 & 1666546.8 & Strict dominance & Strict dominance & Strict dominance \\
\hline Yes & T-SPOT.TB & 150 & 81.4 & 1503603.4 & Strict dominance & Strict dominance & Strict dominance \\
\hline Yes & QFN & 100 & 81.2 & 1290364.5 & $\begin{array}{l}\text { Extended } \\
\text { dominance }\end{array}$ & Extended dominance & $\begin{array}{l}\text { Extended } \\
\text { dominance }\end{array}$ \\
\hline Yes & T-SPOT.TB & 100 & 79.9 & 1761277.3 & Strict dominance & Strict dominance & Strict dominance \\
\hline No & QFN & 40 & 74.9 & 1414623.3 & 9.4 & 325446.8 & 34753.5 \\
\hline Yes & QFN & 40 & 73.4 & 1509353.7 & 1.6 & 94730.4 & 59489.1 \\
\hline No & T-SPOT.TB & 40 & 73.3 & 2095182.0 & $\begin{array}{l}\text { Extended } \\
\text { dominance }\end{array}$ & Extended dominance & $\begin{array}{l}\text { Extended } \\
\text { dominance }\end{array}$ \\
\hline Yes & T-SPOT.TB & 40 & 71.7 & 2189912.4 & 1.7 & 680558.7 & 402421.8 \\
\hline
\end{tabular}

* Ranking different strategies from least effective to most effective (ie, number of cases of active TB predicted to occur) results in the ICERs of most screening options being excluded through extended dominance, which is when the ICER for a particular screening threshold is higher than for the next most effective strategy (screening threshold) and so the higher ICER is removed from the cost-effectiveness analysis.

tCurrent National Institute for Clinical Excellence guidance recommends screening with CXR on arrival, using single-step IGRA or dual TST plus confirmatory IGRA at an incidence threshold of 40/100 000 (bold rows).

CXR, chest $x$-ray; ICER, incremental cost-effectiveness ratio; IGRA, interferon $\gamma$ release assay; LTBI, latent tuberculosis infection; QFN, QuantiFERON Gold in-tube; TST, tuberculin skin test.

TST cut-off and history of BCG vaccination. ${ }^{18-22}$ IGRA performance in diagnosing LTBI in legal (adult) immigrants is poorly studied and has primarily focused on undocumented migrants ${ }^{1920}$ or immigrant contacts of smear-positive cases ${ }^{23} 24$ with few studies focusing on legal, documented migrants. ${ }^{9} 25$ Nonetheless, in all populations, IGRA positivity (15-60\%) has generally been lower than that seen with TST. $^{19}{ }^{20} \quad 23-26$ However, many of these studies have utilised single-step IGRA only $^{25}$ or only undertaken IGRA in individuals who have had a positive TST-thereby introducing bias in patient selection. ${ }^{23}$

Positive TST and IGRA were associated with increasing TB incidence in countries of origin and this likely reflects higher degrees of exposure to Mycobacterium tuberculosis in these settings. This is in keeping with previous analyses for TST $^{1824}$ and IGRA, ${ }^{20} 24$ although there are few data on test positivity in immigrants subcategorised into multiple strata of TB incidence.

Increasing age was also associated with test positivity for all three tests. Previous studies from differing settings and patient groups have shown that TST $^{18} 27$ and IGRA $^{27} 28$ positivity increase with age. Although this is likely to be due to older immigrants having a higher cumulative probability of TB exposure in their countries of origin, other possibilities include higher cumulative exposure to environmental Mycobacteria resulting in false-positive results (for TST) and sub-optimal sensitivity in 
younger age groups resulting in false-negative results (for TST and IGRA). ${ }^{29}$

UK national guidance for immigrant TB screening is currently in flux with the prior LTBI screening threshold (adults from sub-Saharan Africa or countries with TB incidence $>500 / 100$ $000^{7}$ ) missing the vast majority of imported latent infections ${ }^{9}$ now being revised to an incidence of 40/100 000. ${ }^{10}$ While almost all positives in our cohort would be identified using this new recommendation, it would also entail screening most of the immigrant cohort and increase the pressure on already stretched services. ${ }^{8}$ In contrast, with an intermediate threshold (such as $150 / 100000$ ), just under three-quarters of all positives (with single-step IGRA) would be identified but only half the immigrant cohort would need to be tested thereby offering a balance between diagnostic need and practical service capacity. ${ }^{8}$

Our analysis indicates five screening strategies were cost effective-with three strategies more cost effective than current national guidance. These strategies were no port-of-arrival CXR and single-step QFN-GIT at incidence thresholds of 250/100 $000,150 / 100000$ or $40 / 100000$. Introducing port-of-arrival CXR and single-step IGRAs at 40/100 000 was cost effective but at much higher incremental cost-effectiveness ratios. Therefore, while implementing port-of-arrival CXR averts a few additional cases of active $\mathrm{TB}$, it is not highly cost effective (with the findings robust to changes in the prevalence of active TB in immigrants). This finding is consistent with the epidemiology of TB in the UK, where there is little active TB at the time of immigration ${ }^{11} 30$ with most cases occurring through reactivation in latently infected foreign-born immigrants after arrival. ${ }^{2}$ Therefore, screening with mandatory CXR on arrival for active TB should be reassessed. ${ }^{11}$ Other analyses, based on scenarios rather than empirical data, have suggested that CXR screening can be a costeffective intervention but have assumed very high proportions of the immigrant cohort having prevalent active $\mathrm{TB},{ }^{31}$ a very low prevalence of $\mathrm{LTBI}^{32}$ and a low reactivation rate. ${ }^{31} 32$

UK guidance currently recommends that either dual TST plus IGRA or single-step IGRA can be used in adults ${ }^{10}$ but we found that single-step IGRA was the most cost-effective approach. Although previous health economic analyses of immigrant screening were only able to consider TST as a diagnostic modality, ${ }^{3133}$ more recent studies have compared TST and IGRA with varying conclusions-reflecting different modelling techniques and varying estimates of test performance. ${ }^{25} 32$ In nonimmigrant risk groups, the data are conflicting with some authors concluding that TST plus confirmatory IGRA is superior, ${ }^{32}{ }^{34-36}$ while others that IGRA alone is most cost effective. ${ }^{37}$ Although all three individuals with active TB in our dataset were IGRA positive, an important caveat to moving to single-step IGRA would be a requirement to supplement testing with a symptom questionnaire (and potentially CXR if any clinical concerns) to avoid missing immigrants with false-negative IGRAs in the setting of active TB-especially if port-of-arrival CXR is withdrawn.

We also found that QFN-GIT is the most cost-effective IGRA, primarily due to the higher unit costs for T-SPOT.TB. Previous economic analyses of IGRAs (including among immigrants) have, in general, only focused on one or other IGRA. Only Pooran et al assessed the relative cost effectiveness of QFN-GIT and T-SPOT.TB, but their analysis focused on contacts, only considered a 2-year time horizon, did not include discounting, and most importantly, used now superseded estimates of test performance. ${ }^{34}$

Central to our analysis is the specific threshold at which screening should be instigated: 250/100 000, 150/100 000 and
40/100 000 were all cost-effective thresholds, confirming previous work, ${ }^{9}$ and the latter two strategies would include immigrants from the Indian subcontinent who contribute both a large proportion of the individuals migrating to, and a high proportion of the foreign-born active $\mathrm{TB}$ cases occurring in, the UK. $^{2}{ }^{39}$ Optimal screening thresholds in different high-income countries may differ due to local patterns of migration and countries should ascertain their specific mix/pattern of migration and prevalence of LTBI to most accurately parameterise health economics models.

Our work had several limitations. The number of participants was relatively small and not all were concurrently screened with all three tests. While the composition of immigrants screened was broadly in keeping with the foreign-born population resident in the UK, other areas of the UK may have slightly higher proportions of immigrants from the Indian subcontinent. As per UK guidelines, HIV testing was not undertaken and thus data on immigrants' HIV status were not available. Consequently we used estimates for this but our work highlights the potential of incorporating testing for bloodborne viruses into communitybased screening for TB.

Our health economics model only considered transmission to contacts resulting in secondary cases of active TB and LTBI. Incorporating further generations of transmission would increase the cost effectiveness of screening by increasing the number of cases ultimately averted. However, we assumed relatively high rates of acceptance and completion of chemoprophylaxis which, while broadly in line with the estimates used by NICE, ${ }^{10}$ may have overestimated the cost effectiveness of screening (although the results remained broadly unchanged with reductions in completion rates). We only considered incidence thresholds $>40 / 100000$ but future work should ascertain the cost effectiveness, and logistics, of screening immigrants at lower incidence thresholds (such as $>20 / 100000$ ).

In line with previous published work 31323437 we elected to assess cost effectiveness by presenting the cost per active TB case averted rather than the cost per quality adjusted life year as there are still limited objective data on utility states for individuals with active and latent TB.

In conclusion, immigrant screening in the UK could costeffectively remove the requirement for mandatory CXR on arrival and concentrate on screening for LTBI with single-step IGRA at an incidence threshold which balances the need to identify those with LTBI against limited service capacity while still reducing UK TB notifications in the future.

\section{Author affiliations}

${ }^{1}$ Department of Respiratory Medicine, Tuberculosis Research Unit, National Heart and Lung Institute, Imperial College London, London, UK

${ }^{2}$ Department of Infectious Disease Epidemiology, MRC Centre for Outbreak Analysis and Modelling, Imperial College London, London, UK

${ }^{3}$ Tuberculosis Service, Chest and Allergy Clinic, St Mary's Hospital, Imperial College Healthcare NHS Trust, London, UK

${ }^{4}$ Department of Clinical Immunology, St Mary's Hospital, Imperial College Healthcare NHS Trust, London, UK

${ }^{5}$ Formerly Director of Public Health/Medical Director, Westminster Primary Care Trust, London, UK

${ }^{6}$ Modelling and Economics Unit, Health Protection Agency, London, UK

Acknowledgements The authors wish to acknowledge the contribution of the local primary care centres that ran the new entrant screening programmes: Lisson Grove Health Centre, Soho Square General Practice, Newton Medical Centre and the 574 Harrow Road Practice.

Contributors The initial study was designed and set up by OMK and MG with input by MP and AL. MB and JS undertook the immigrant screening and entered the data into the databases. SS was in charge of setting up and analysing the IGRA results. MP analysed the data and designed the economic model with input from 
OMK, AL and PJW. MP drafted the manuscript with input from all other authors. All authors approved the final version to be published. OMK is the guarantor.

Funding This study was undertaken at St Mary's Hospital, Imperial College Healthcare NHS Trust which is supported by the NIHR Biomedical Research Centre funding scheme. Westminster Primary Care Trust provided funding for the project. MP is funded by a Medical Research Council Capacity Building Studentship. PJW thanks the Medical Research Council for Centre funding. AL is a Wellcome Senior Research Fellow in Clinical Science and NIHR Senior Investigator.

Competing interests $\mathrm{AL}$ is inventor for patents underpinning T-cell-based diagnosis. The ESAT-6/CFP-10 ELISpot was commercialised by an Oxford University spin-out company (Oxford Immunotec, Abingdon, UK) in which Oxford University and Professor Lalvani have a minority share of equity. MP, SS, MB, JS, MG, PJW and OMK have no conflict of interest.

Ethics approval No patient-specific data or personal identifiers were used in the preparation of this report which was an analysis of routine data collected as part of service evaluation and therefore ethical approval was not required.

Provenance and peer review Not commissioned; externally peer reviewed.

Data sharing statement Full numerical results of the scenarios described here are available from the corresponding author on request.

\section{REFERENCES}

1 European Centre for Disease Prevention and Control. Migrant Health: Background Report to the ECDC Report on Migration and Infectious Diseases in the EU. Stockholm: European Centre for Disease Prevention and Control, 2009.

2 Health Protection Agency. Tuberculosis in the UK: Annual Report on Tuberculosis Surveillance and Control in the UK 2010. London: Health Protection Agency Centre for Infections, 2010.

3 EURO-TB. Total TB Cases and TB Notification Rates, 1995-2006. Saint Maurice: WHO European Region, 2006.

4 Office for National Statistics. Total International Migration (TIM) Tables: 1991Latest. London: ONS, 2007.

5 Gilbert RL, Antoine D, French CE, et al. The impact of immigration on tuberculosis rates in the United Kingdom compared with other European countries. Int I Tuberc Lung Dis 2009;13:645-51.

6 Moore-Gillon J, Davies PD, Ormerod LP. Rethinking TB screening: politics, practicalities and the press. Thorax 2010;65:663-5.

7 National Collaborating Centre for Chronic Conditions. Tuberculosis: Clinical Diagnosis and Management of Tuberculosis, and Measures for its Prevention and Control. London: Royal College of Physicians, 2006

8 Pareek M, Abubakar I, White PJ, et al. TB screening of migrants to low TB burden nations: insights from evaluation of UK practice. Eur Respir J 2011;37:1175-82.

9 Pareek M, Watson JP, Ormerod LP, et al. Screening of immigrants in the UK for imported latent tuberculosis: a multicentre cohort study and cost-effectiveness analysis. Lancet Infect Dis 2011;11:435-44.

10 National Collaborating Centre for Chronic Conditions. Tuberculosis: Clinical Diagnosis and Management of Tuberculosis, and Measures for its Prevention and Control. London: Royal College of Physicians, 2011.

11 Health Protection Agency. Port Health and Medical Inspection Review: Report from the Project Team. London: Health Protection Agency, 2006.

12 Arshad S, Bavan L, Gajari K, et al. Active screening at entry for tuberculosis among new immigrants: a systematic review and meta-analysis. Eur Respir J 2010;35:1336-45.

13 Erkens C, Slump E, Kamphorst M, et al. Coverage and yield of entry and follow-up screening for tuberculosis among new immigrants. Eur Respir J 2008;32:153-61.

14 Office for National Statistics. Annual Population Survey: Population by Country of Birth and Nationality October 2009 to September 2010. London: Office for National Statistics, 2010

15 Health Protection Agency. Three-year Average Tuberculosis Case Reports and Rates by Primary Care Trust, England, 2006-2008. London: Health Protection Agency, 2009.

16 Department of Health. Immunisation Against Infectious Disease- "The Green Book". London: HMSO, 2006.
17 Lalvani A, Pareek M. A 100 year update on diagnosis of tuberculosis infection. $\mathrm{Br}$ Med Bull 2009;93:69-84.

18 Li J, Munsiff SS, Agerton TB. Prevalence of tuberculin skin test positivity in clinical population in New York City. J Immigr Minor Health 2010;12:816-22.

19 Saracino A, Scotto G, Fornabaio C, et al. QuantiFERON-TB Gold In-Tube test (QFT-GIT) for the screening of latent tuberculosis in recent immigrants to Italy. New Microbiol 2009:32:369-76.

20 Orlando G, Merli S, Cordier L, et al. Interferon- $\gamma$ releasing assay versus tuberculin skin testing for latent tuberculosis infection in targeted screening programs for high risk immigrants. Infection 2010:38:195-204.

21 Wells CD, Zuber PL, Nolan CM, et al. Tuberculosis prevention among foreign-born persons in Seattle-King County, Washington. Am J Respir Crit Care Med 1997;156:573-7.

22 Bothamley GH, Rowan JP, Griffiths CJ, et al. Screening for tuberculosis: the port of arrival scheme compared with screening in general practice and the homeless. Thorax 2002:57:45-9.

23 Kik SV, Franken WP, Arend SM, et al. Interferon-gamma release assays in immigrant contacts and effect of remote exposure to Mycobacterium tuberculosis. Int I Tuberc Lung Dis 2009;13:820-8.

24 Janssens JP, Roux-Lombard P, Perneger T, et al. Contribution of a IFN-gamma assay in contact tracing for tuberculosis in a low-incidence, high immigration area. Swiss Med Wkly 2008;138:585-93

25 Hardy AB, Varma R, Collyns T, et al. Cost-effectiveness of the NICE guidelines for screening for latent tuberculosis infection: the QuantiFERON-TB Gold IGRA alone is more cost-effective for immigrants from high burden countries. Thorax 2010;65:178-80.

26 Carvalho AC, Pezzoli MC, El-Hamad I, et al. QuantiFERON-TB Gold test in the identification of latent tuberculosis infection in immigrants. J Infect 2007;55:164-8.

27 Shanaube K, Hargreaves J, Fielding K, et al. Risk factors associated with positive QuantiFERON-TB Gold in-tube and tuberculin skin tests results in Zambia and South Africa. PLoS One 2011:6:e18206

28 Mutsvangwa J, Millington KA, Chaka K, et al. Identifying recent Mycobacterium tuberculosis transmission in the setting of high HIV and TB burden. Thorax 2010;65:315-20

29 Bamford AR, Crook AM, Clark JE, et al. Comparison of interferon-gamma release assays and tuberculin skin test in predicting active tuberculosis (TB) in children in the UK: a paediatric TB network study. Arch Dis Child 2010;95:180-6.

30 Millership S, Cummins A. Identification of tuberculosis cases by port health screening in Essex 1997-2003. J Public Health (Oxf) 2005:27:196-8.

31 Schwartzman K, Menzies D. Tuberculosis screening of immigrants to low-prevalence countries. A cost-effectiveness analysis. Am J Respir Crit Care Med 2000;161:780-9.

32 Oxlade $\mathrm{O}$, Schwartzman K, Menzies D. Interferon-gamma release assays and TB screening in high-income countries: a cost-effectiveness analysis. Int I Tuberc Lung Dis 2007;11:16-26.

33 Dasgupta K, Schwartzman K, Marchand R, et al. Comparison of cost-effectiveness of tuberculosis screening of close contacts and foreign-born populations. Am J Respir Crit Care Med 2000;162:2079-86.

34 Pooran A, Booth H, Miller RF, et al. Different screening strategies (single or dual) for the diagnosis of suspected latent tuberculosis: a cost effectiveness analysis. BMC Pulm Med 2010;10:7.

35 Diel R, Wrighton-Smith P, Zellweger JP. Cost-effectiveness of interferon-gamma release assay testing for the treatment of latent tuberculosis. Eur Respir 2007;30:321-32.

36 Marra F, Marra CA, Sadatsafavi M, et al. Cost-effectiveness of a new interferon-based blood assay, QuantiFERON-TB Gold, in screening tuberculosis contacts. Int J Tuberc Lung Dis 2008:12:1414-24.

37 Diel R, Nienhaus A, Loddenkemper R. Cost-effectiveness of interferon-gamma release assay screening for latent tuberculosis infection treatment in Germany. Chest 2007:131:1424-34

38 Diel $\mathrm{R}$, Schaberg $\mathrm{T}$, Loddenkemper $\mathrm{R}$, et al. Enhanced cost-benefit analysis of strategies for LTBI screening and INH chemoprevention in Germany. Respir Med 2009;103:1838-53

39 Office for National Statistics. Total International Migration (TIM) Tables: 1991Latest. London: ONS, 2010. 